\title{
NATO and earth scientists: an ongoing collaboration to assess geohazards and contribute to societal security in Central Asia and the Caucasus
}

\author{
${ }^{1}$ Department of Earth and Environmental Sciences, University of Milano-Bicocca, P. della Scienza 4, 20126 Milan, Italy; *Corresponding \\ author, E-mail: alessandro.tibaldi@unimib.it \\ ${ }^{2}$ Laboratory of modelling of seismic processes, Institute of Communication and Information Technologies, Kyrgyz-Russian Slavic University, \\ Kievskaya str. 44, Bishkek 720000, Kyrgyz Republic \\ ${ }^{3}$ Department of Theoretical and Applied Sciences, University of Insubria, Via Mazzini 5, 21100 Varese, Italy \\ ${ }^{4}$ School of Earth and Environmental Sciences, University of Portsmouth, Barnaby Building, Portsmouth PO1 2UP, UK \\ ${ }^{5}$ M. Nodia Institute of Geophysics, M. Javakhishvili Tbilisi State University, 1, Alexidze str. 0171 T, Georgia
}

(Received: July 18, 2017; Revised accepted: February 26, 2018)

https://doi.org/10.18814/epiiugs/2018/018011

Geological features and hazards have no geographical and political boundaries. The North Atlantic Treaty Organization (NATO) has been funding several international Earth Science research projects in Central Asia and the Caucasus over the last ten years. The projects are aimed at improving the security of people and the safety of infrastructures, and fostering peaceful scientific collaboration between scientists from NATO and non-NATO countries. In the present work, we show how Earth Science can contribute to improving scientific collaboration also among countries that are politically in tension, and how it can also play a key role in preventing situations that may escalate into conflicts. This paper showcases the main results, partially unpublished, of three different research projects that have been aimed at assessing, through an interdisciplinary approach, different geohazards affecting important infrastructure and lifelines of a number of countries in Central Asia and the Caucasus. For each region, we also describe the societal relevance of the research, considering possible geopolitical issues that might be brought about by natural disasters. The research efforts have focused on geohazards threatening: i) the Enguri hydropower plant, located partly in the Republic of Georgia and partly in the disputed territory of Abkhazia, ii) the Toktogul water reservoir, in Kyrgyzstan, and iii) the Caspian oil and gas pipelines crossing the Republic of Georgia.

\section{Introduction}

Several areas on Earth are subject to natural hazards that threaten human life, settlements and infrastructures. One of the natural hazards that may severely affect local areas and communities is an earthquake, as seen, for instance, in the recent sequence of seismic events that struck the Caucasus: the 1988 earthquake in Spitak, Armenia (Griffin et al., 1991), the 1991 and 2009 Racha (Georgia) earthquakes (Nikolaeva and Walter, 2016) and the 2000 Baku earthquake in Azerbaijan (Babayev et al., 2010). However, geological-related extreme events often cause adverse feedback effects that are felt in regions well beyond the originally affected areas. For example, if an earthquake destroys a major infrastructure, such as a large hydroelectrical power plant, the consequences of the interruption in energy production and supply can affect a whole country and produce major economic loss to millions of people. Worse still, if a natural disaster strikes a major infrastructure located at the border between two countries, the consequences can cause international tension, which can eventually escalate and lead to a conflict.

The North Atlantic Treaty Organization (NATO) has been funding the major Science for Peace and Security Programme (SPS), which enhances cooperation and dialogue among different countries, based on scientific research, innovation and knowledge exchange. The focus is on carrying out security-relevant activities jointly conducted by scientists belonging to at least one NATO member country and one partner country. With the purpose of improving understanding of the geological hazards that might negatively affect the safety of an infrastructure of high international societal and political relevance, as well as suggesting mitigation measures aimed at preventing possible geopolitical problems, three major research programmes have been launched, and two completed, in Central Asia and the Caucasus over the last ten years, under the aegis of NATO-SPS. All these research 


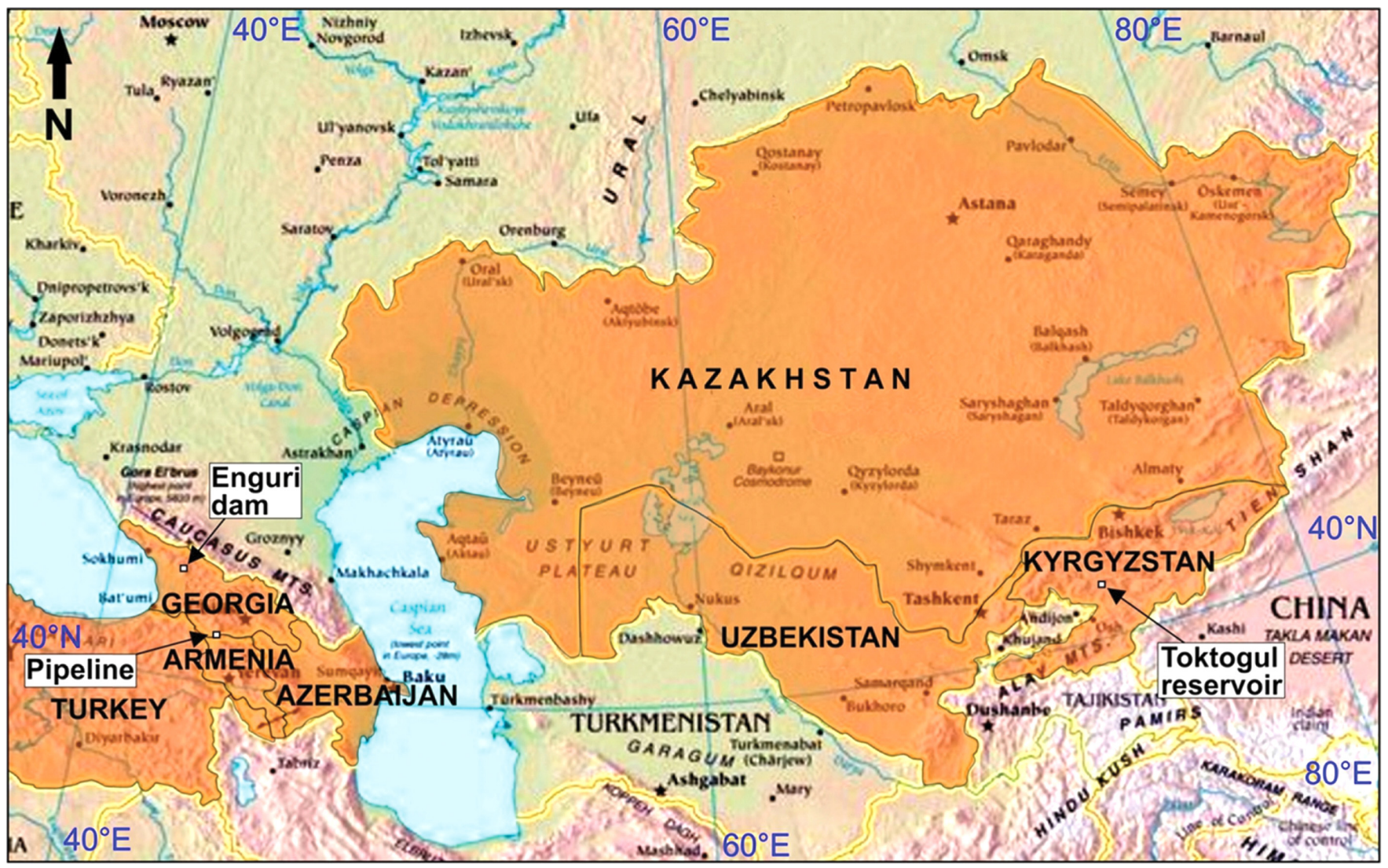

Figure 1. Location of the study areas (arrows). The NATO-partner countries involved in the here-described projects are highlighted in orange.

efforts involve countries that were made independent by the dissolution of the former Soviet Union (Fig. 1) and focus on geologicalrelated threats to major energy-related infrastructures. Damage to those facilities might affect the societal and political stability of the region and eventually bring about international conflicts. Similarly, an extreme geological event in one country may produce adverse consequences to its neighbouring countries. In either case, international collaboration is necessary.

The aim of this paper is to illustrate the main results, partially unpublished, of these three research projects, in order to show the pivotal role that can be played by Earth Science in maintaining and ensuring peace. In this sense, the proactive work of Earth scientists can: i) assess the origin and magnitude of the geological hazards affecting an area, ii) foster collaboration among scientists from different countries, and mitigate possible existing tensions, and iii) directly contribute to the security of people and the safety of infrastructure by involving end-users and encouraging them to take preventive mitigation measures. The three research examples shown here were chosen owing to their international appeal: They involve interdisciplinary methodologies and are related to different geohazards, including those associated with landslides, seismicity and volcanism. For each research area, we have also described the societal relevance of the study, including possible geopolitical issues that might be triggered by natural disasters. The research examples presented hereunder are relative to the geohazards threatening: i) the Enguri hydropower plant, located partly in the Republic of Georgia and partly in the disputed territory of Abkhazia, ii) the Toktogul hydroelectric and irrigation scheme in Kyrgyzstan, and iii) the Caspian oil and gas pipelines crossing the Republic of Georgia.

\section{The Enguri Hydropower Plant, Republic of Georgia}

\section{Geohazard Framework}

This research is being carried out, in the 2015-2018 time period, by a group of 25 scientists from Italy, the United States, the United Kingdom, Switzerland, Georgia, Azerbaijan and Kazakhstan (as shown on the map in Fig. 1). The project focuses on assessing the vulnerability to geohazards of the largest hydroelectrical facility in the Republic of Georgia - the Enguri dam and associated reservoir (Fig. 2) - and identifying the possible different geohazard scenarios that might take place, the preventive measures which can be realistically adopted by the main end-users, and the training activities that can be implemented for improving the background and know-how of young researchers and technicians. The Enguri dam (the world's sixth highest) is part of the Enguri Hydroelectric power station (EHS) that is partially located in Abkhazia, the separatist region of Georgia. The huge 'Khoko' landslide is located along one side of the reservoir. The collapse of this landslide into the reservoir might trigger a major catastrophe. Despite the very steep slopes surrounding the reservoir and the high seismicity of the region, no quantitative assessment of slope stability has ever been performed under dynamic conditions. 


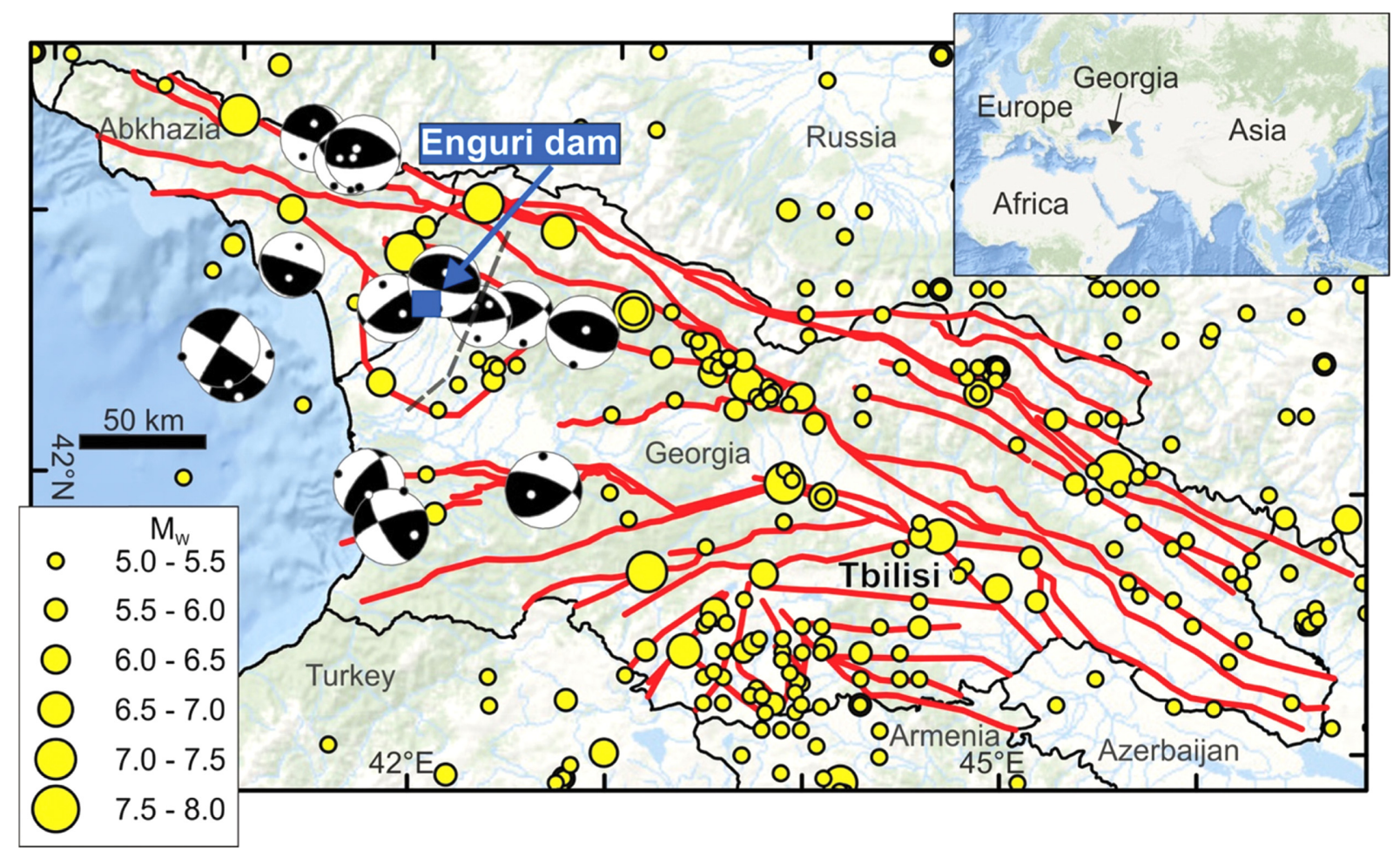

Figure 2. Active faults in the Georgian Caucasus (red lines) (Tsereteli et al., 2016). Main earthquake epicentres (yellow circles) with magnitude Mw proportional to circle diameter, and location of the Enguri dam (blue rectangle). Focal mechanisms refer to the earthquakes around the Enguri dam (modified after Tsereteli et al., 2016). The dashed black line gives trace of the geological section of Figure 4.

Special concern arises from potential earthquakes affecting the steep, landslide-prone slopes. Seismically-induced ground shaking greatly increases the likelihood that landslides may occur, also through the dynamic increase in pore pressure and dilation of soil materials that causes rapid infiltration of water. In this regard, the EHS is located in the foothills of the western Greater Caucasus, one of the most tectonically active areas in the world (Tsereteli et al., 2016). This region is crossed by tens to hundreds, long active faults whose strike is mostly parallel to the mountain range (Fig. 2). Philip et al. (1989) pointed out that deformation in the western Greater Caucasus is concentrated along its southern slope, while the northern flank is almost undeformed; this suggests that the whole shortening across the western Greater Caucasus is absorbed along the southern border of the range, where the Enguri dam is located. This shortening was estimated to $2-6 \mathrm{~mm} / \mathrm{yr}$ (Reilinger et al., 2006).

Analysis of the historical and instrumental seismological data of Georgia shows that the strongest earthquake was characterised by Ms 7 and macroseismic intensity 9 (MSK scale) (Tsereteli et al., 2016; Varazanashvili et al., 2018). The present seismic hazard zonation map ( $2 \%$ probability of exceedance in $50 \mathrm{ys)}$ of Georgia (SHZG) (Chelidze et al., 2002), which was adopted officially in 2010, suggests a possible scenario of earthquake ground shaking with a Peak Ground Acceleration (PGA) of 0.1-0.56. The same results are shown in the work by Van Westen et al. (2012). Although the SHZG assigns to two faults located near the Enguri dam a potential to produce earthquakes as strong as Ms 6-7, the expected PGA is underestimated if compared with more recent results (Tsereteli et al., 2014). This suggests the need for a careful reassessment, incorporating the results of paleo- seismic investigations, which represent a major focus of this project.

\section{Results}

\section{Seismic hazard}

We integrated field geological, geomorphological and structural data with seismic reflection geophysical data in order to locate prehistoric surface fault ruptures in an area with a $45-\mathrm{km}$ radius from the Enguri dam. Aerial photos are only partially available for this area and thus we used SPOT satellite images with a $2.5 \mathrm{~m}$ resolution for identifying morphostructural features. By integrating satellite images with field surveys, we observed that the area near the dam is marked by the presence of strongly entrenched rivers, which in turn suggest major tectonic uplift. The area south of the dam is characterized by widespread fluvial deposits that date from late Miocene to Present times. This succession can also be interpreted as the evidence of major uplift of this part of the Caucasus with consequent erosion, consistent with fission-track studies (Vincent et al., 2011). The oldest part of the fluvial succession also shows evidence of tectonic folding. We recognised field evidence of active folding in correspondence of the Tsaishi fold, located $45 \mathrm{~km}$ south of the Enguri dam (Fig. 3a). This evidence is represented by: $i$ ) the diversion of the rivers coinciding with the fold; ii) the gentle anticlinal folding of the river terraces; iii) the preservation of terrace surfaces and deposits up to 120 metres above the present river; moreover, seismic reflection sections (e.g., in Fig. 3b) show Pliocene layers involved in the folding (Tibaldi et al., 2017). Historical earthquake data locate the historic Tsaishi earth- 


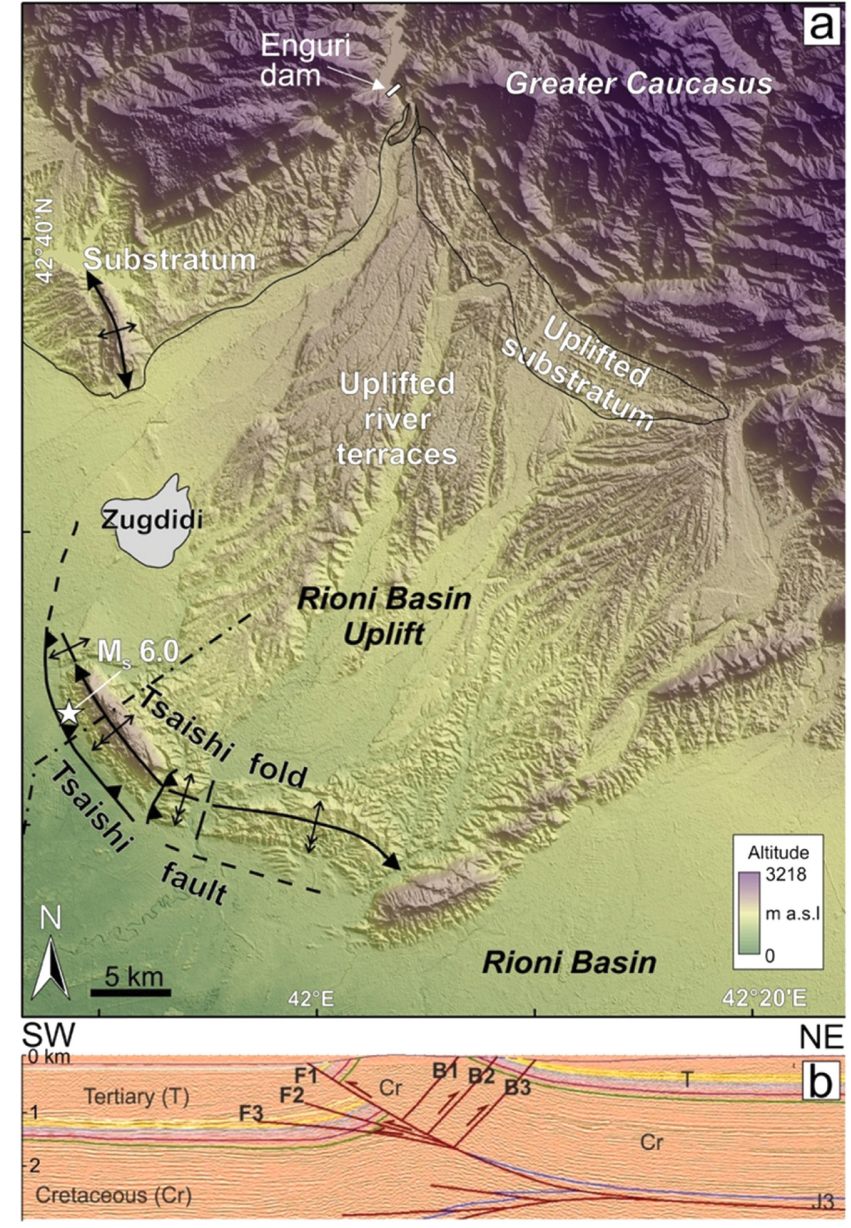

Figure 3. (a) Main neotectonic features around the Enguri dam. The extension of the Zugdidi town is highlighted in grey. White star locates the site where the 1614 Tsaishi earthquake occurred. (b) Seismic reflection section across the Tsaishi fold; the trace is indicated by the $\mathrm{NE}-\mathrm{SW}$ dashed line in Figure 3a. Modified after Tibaldi et al. (2017).

quake of $1614 \mathrm{AD}$ at the southwestern foot of the fold (Varazanashvili et al., 2011), with an epicentral Intensity of 8-9 and a magnitude (Ms) 6.0. This location also coincides with a morphological scarp located at the foot of the fold and that runs parallel to the fold hinge (i.e., NW-SE). We interpreted all these data as evidence that Tsaishi is a fault-propagation fold linked with the seismic activity along a reverse fault dipping towards the NE. We merged these data with regional geological and geophysical data resulting in the section of
Figure 4, which shows the Tsaishi fault connecting northward with a thrust system displaying ramps and flats below the Enguri site.

\section{Landslide hazard}

The eastern slopes of the Enguri reservoir are affected by a number of active landslides. No study has been published on these landslides so far. Therefore, our effort can help assess the present-day degree of stability of these landslides and their possible behaviour in case of earthquake shaking under different conditions of water content. The quantitative evaluation of the static and dynamic behaviour of these landslides under different possible scenarios, as well as of other instability-prone slopes around the reservoir, will enable preventing and mitigating the effects of potential landslide-related events. This is particularly relevant because the Enguri hydroelectrical plant is an infrastructure of key importance: in the event of a possible landslide occurrence, the hydroelectrical plant would temporarily be out of commission, with major problems to the whole country in terms of energy supply and national productivity. Moreover, the collapse of rock debris into the artificial lake would produce the partial infilling and long-term decrease in the capacity of the hydroelectric plant. In order to tackle this hazardous situation, we are developing the first numerical model of stability of the most critical slope surrounding the reservoir (Fig. 5a). The model, presented here for the first time, is based on the integration of field geological surveys with geotechnical tests and drill logs from the Soviet era, which were performed in the area now covered by the reservoir (Fig. 5c). A new geological cross section has been prepared, which considers three main geological units: an intact Jurassic sandstone and tuff bedrock below the basal slip surface, an upper unit made of debris with clay and gypsum fragments, and an old landslide deposit. In the numerical model, we plan on introducing a further geotechnical unit corresponding to fragmented sandstone-tuff deposits resting above the basal slip surface. The water table is simulated based on several piezometric wells located across the slope. Measurements made in different days in May 2017 indicate the complete water saturation of the slope. Thus, we plan on modeling slope stability based on the variation of the water saturation and the level of the reservoir. In order to continuously monitor the evolution of instability-related processes in the area, we installed a series of digital extensiometers that will be assessing slope movements with a 0.1-mm resolution (e.g., Fig. 5b). Global Positioning System benchmarks have also been installed, which will be measured at 6-month intervals to record the displacement of the upper portion of the landslide. Further analyses will comprise a numerical study of the landslide

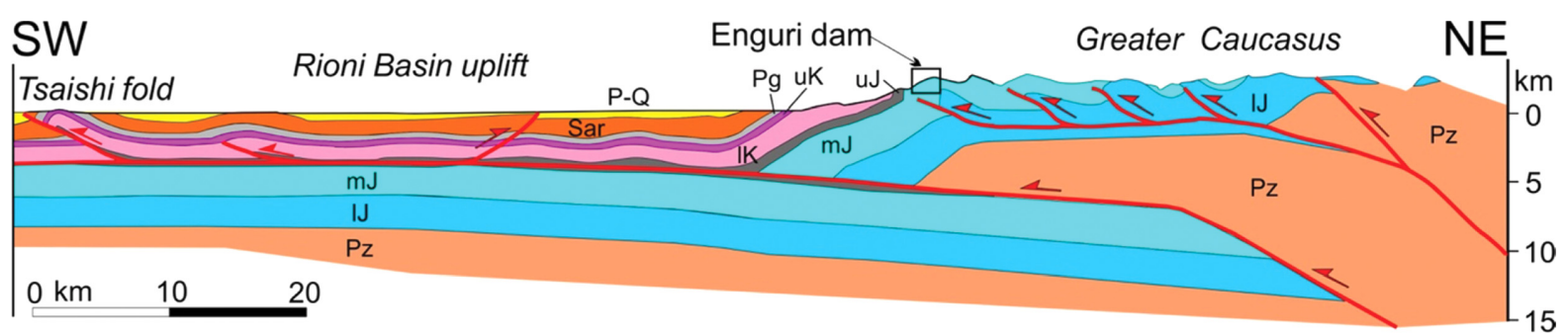

Figure 4. Structural crustal section elaborated by combining our field data and seismic reflection sections from Tibaldi et al. (2017) with data published in Banks et al. (1997). Trace in Figure 2. Pz: Paleozoic, IJ: lower Jurassic, mJ: middle Jurassic, uJ: upper Jurassic, IK: lower Cretaceous, uK: upper Cretaceous, Pg: Paleogene, Sar: Sarmatian, P-Q: Pliocene-Quaternary. 

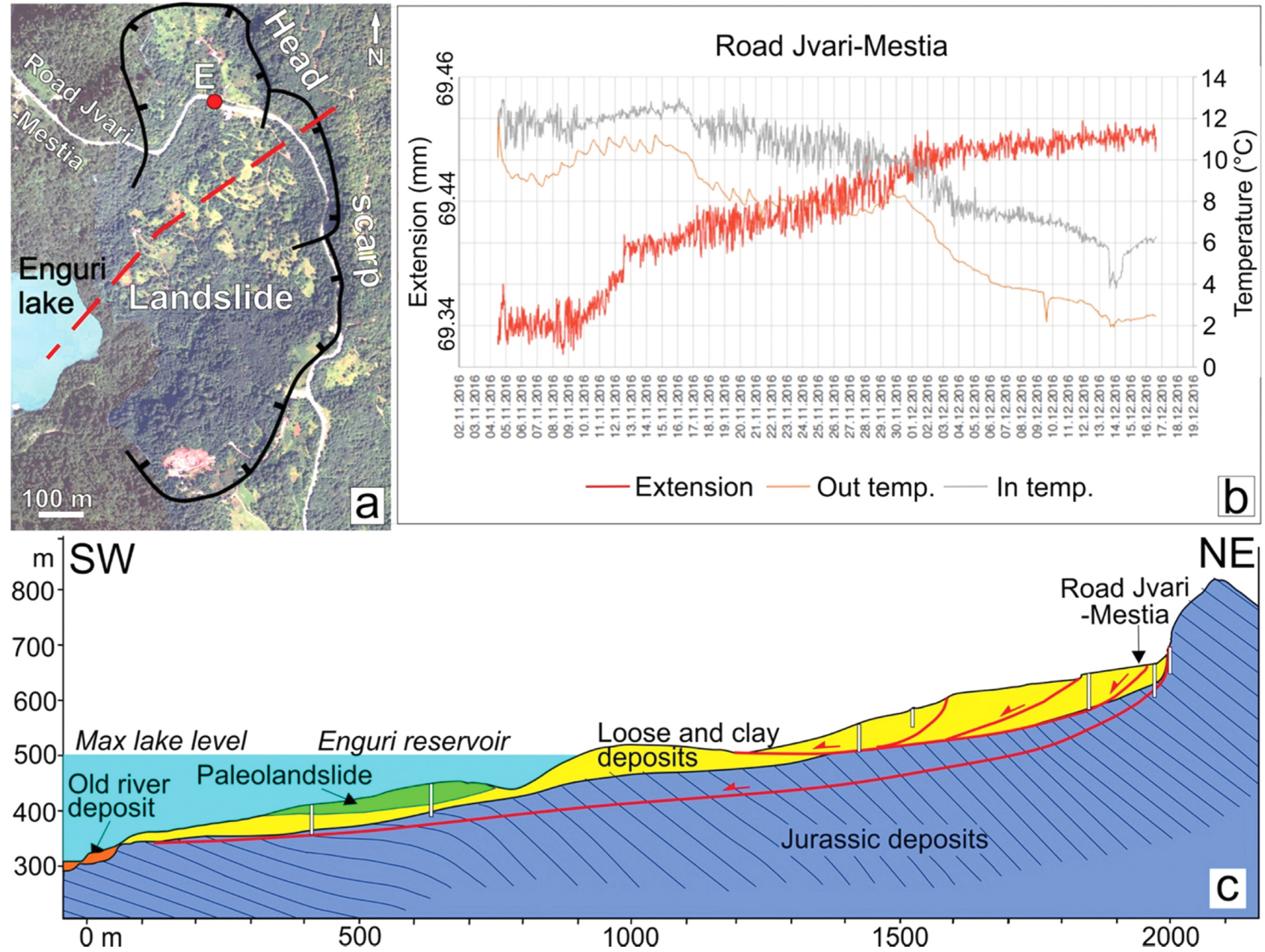

Figure 5. (a) Plan view of the landslide facing the Enguri water reservoir. Point (E) locates the extensiometer; the red dashed line locates the section of Figure 5c. (b) Extension and temperature measurements in point E (location in Fig. 5a). (c) Geological section across the landslide with location of the logs (white bars) used for reconstructing the deposit succession (trace in Fig. 5a).

under dynamic conditions, based on the outputs of the seismological and geological-structural field surveys and recalculation of the PGA, and comparison with variations in the lake level.

\section{Societal Implications: Geohazards and Political Stability of the Region}

Problems to the EHP would affect the energy distribution across Georgia, because most of the energy to the country is supplied by this plant. The same problem would affect Abkhazia, where the entire energy supply comes from this plant. Moreover, possible overflooding from the reservoir would directly affect eastern Abkhazia. A stop in energy production may cause severe economic losses in both areas and increase local societal and political instability, leaving millions of residents and several tens of infrastructures such as hospitals and military bases without energy supply. This might have the effect of worsening the already tense relations between Abkhazia and the Georgian government. The situation is rooted in the status of Abkhazia, a region that was autonomous within Georgia during the Soviet Union era and claimed independence when the Soviet Union began to disintegrate. This erupted into the War of Abkhazia in 1992, which left 13,000 to 20,000 Georgians and 3000 Abkhaz killed, with about 250,000 Georgians forced into internal displacement as refugees (Tibaldi and Pasquarè Mariotto, 2017). This was followed by another conflict in 1998, when hundreds of Abkhaz militants entered villages of the Gali district, still populated by Georgians, leading to hundreds of casualties from both sides and further 20,000 Georgian refugees. There was another crisis in 2001, followed by the dramatic 2008 conflict, during which Russian troops coming from Abkhazia occupied the city of Zugdidi, ran raids on military bases located deeper within Georgia, and occupied the important harbour of Poti, along the Georgian Black Sea coast. The administrative line between Abkhazia and Georgia was moved eastward to the Enguri River, which still marks most of the de facto present-day border. At present, the Abkhazian territory is a self-proclaimed state, recognised by the governments of Russia, Nicaragua, Venezuela and Nauru. In the last few years the situation has worsened, with the closure of four out of six border-crossing points, which has been causing major problems to local residents living on either side of the border.

The people living at the foothills of the Enguri dam are not only troubled by the political and economic situation, but they are also worried about the potential threat posed by earthquake hazard, as well 


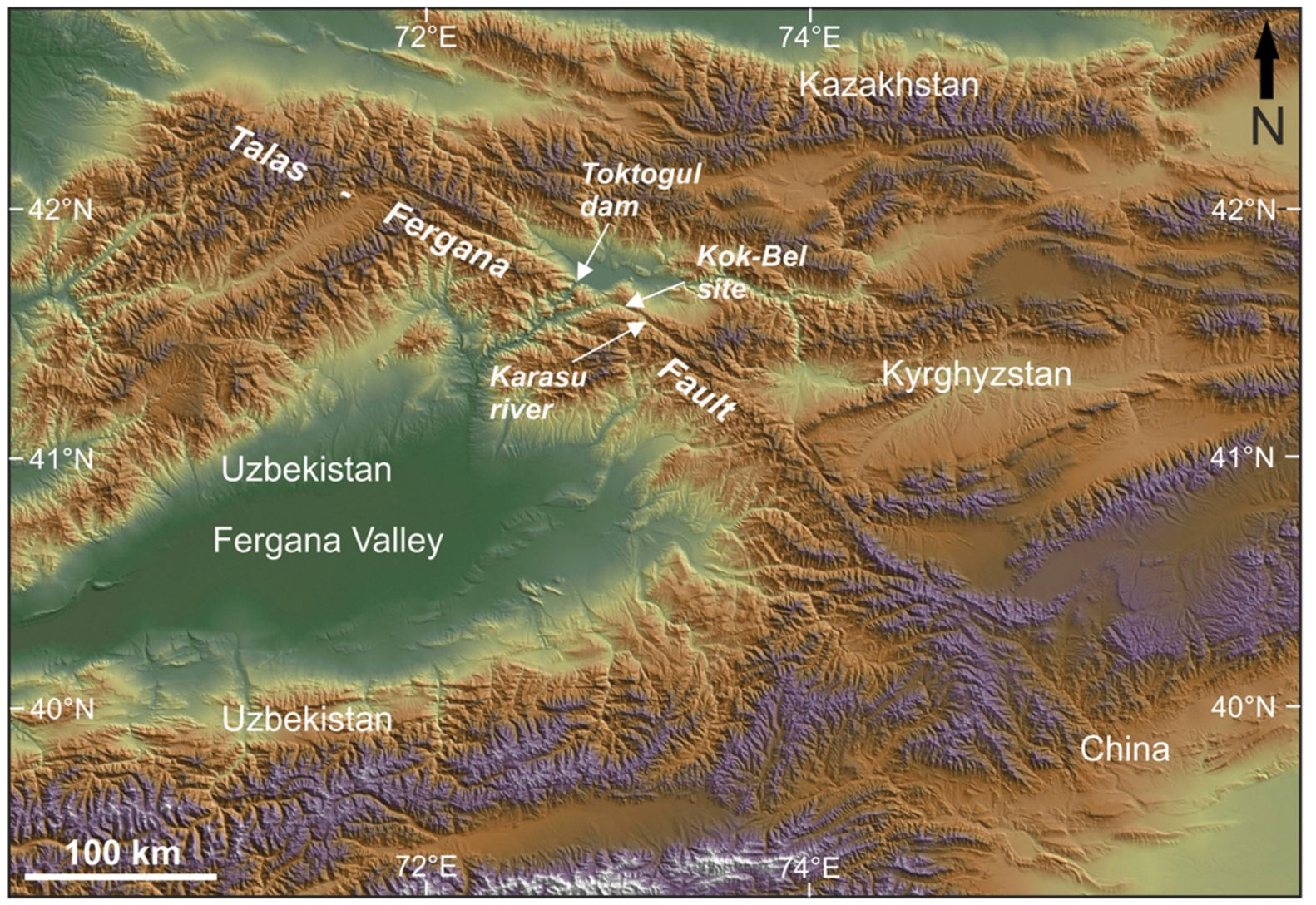

Figure 6. The Talas-Fergana Fault is visible in DEM of western Tien Shan mountain belt. Locations discussed in the text are highlighted.

by the possible collapse of a landslide into the lake. In this regard, scientists from NATO countries and NATO-partner countries are improving knowledge of the area, and have already taken proactive measures by involving end-users such as the Georgian Ministry of Regional Development and Infrastructure, the Georgian Ministry for Energy, the Georgian Emergency Management Center and the Enguri Dam Company. Moreover, all the efforts taken to monitor the landslide and other research activities have been communicated to the local population, thus raising public awareness.

\section{The Toktogul Reservoir and The Talas-Fergana Fault, Kyrgyzstan}

\section{Geohazard Framework}

The 2008-2013 NATO-funded project involved the United Kingdom, Italy, Kyrgyzstan and Uzbekistan (as shown on map in Fig. 1); the Uzbek team resigned later on due to country-internal political reasons. The project had the purpose of assessing the potential geological-environmental hazards affecting the Toktogul Hydro-Power Station (HPS), a strategic infrastructure for Kyrgyzstan and the neighbouring central Asian republics. The HPS dam, a 215-m-high concrete arch structure, impounds the Naryn River to produce the Toktogul reservoir, the largest of its kind in Central Asia (surface area $284 \mathrm{~km}^{2}$, volume $19.5 \mathrm{~km}^{3}$, production capacity $1200 \mathrm{MW}$ ). The well-known, NW-SE striking, regional Talas-Fergana right-lateral strike-slip fault is near the dam and reservoir and transects the Tien Shan orogenic belt (Fig. 6). The $\sim 700 \mathrm{~km}$ length of the fault is characterised by the typical features associated with paleoseismic deformation, including scarps, offset streams and drainage divides, as well as landslides (Burtman et al., 1987, 1996; Trifonov et al., 1992, 2015; Korjenkov et al., 2010, 2012, 2013; Korzhenkov et al., 2014; Tibaldi et al., 2015; Rust et al., 2018). Nevertheless, modern seismic networks reveal only small and rare moderate seismicity along the fault zone, whereas GPS measurements do not provide any evidence of active deformation along the Talas-Fergana Fault, suggesting it is presently locked.

The NATO-supported team conducted extensive fieldwork, comprising paleoseismic and slope stability analyses, aimed at finding evidence of historical and Holocene ground-rupturing earthquakes, coupled with detailed interpretations of aerial photos and new detailed (50-cm resolution) Digital Elevation Models (DEMs) of several areas especially prepared by way of electronic tacheometer surveys. The team also carried out a landslide hazard assessment near the HPS. Both geohazard sources were recognized as significant potential threats to the Toktogul region.

\section{Results}

We used trench excavations across the Talas-Fergana Fault with application of paleoseismic techniques aimed at dating the occurrence of prehistoric earthquakes. Very detailed topographic surveys allowed to precisely quantify the offsets of dated landforms, useful for calculating fault slip rate at the Kök-Bel site (Fig. 7). By doing so, we were 


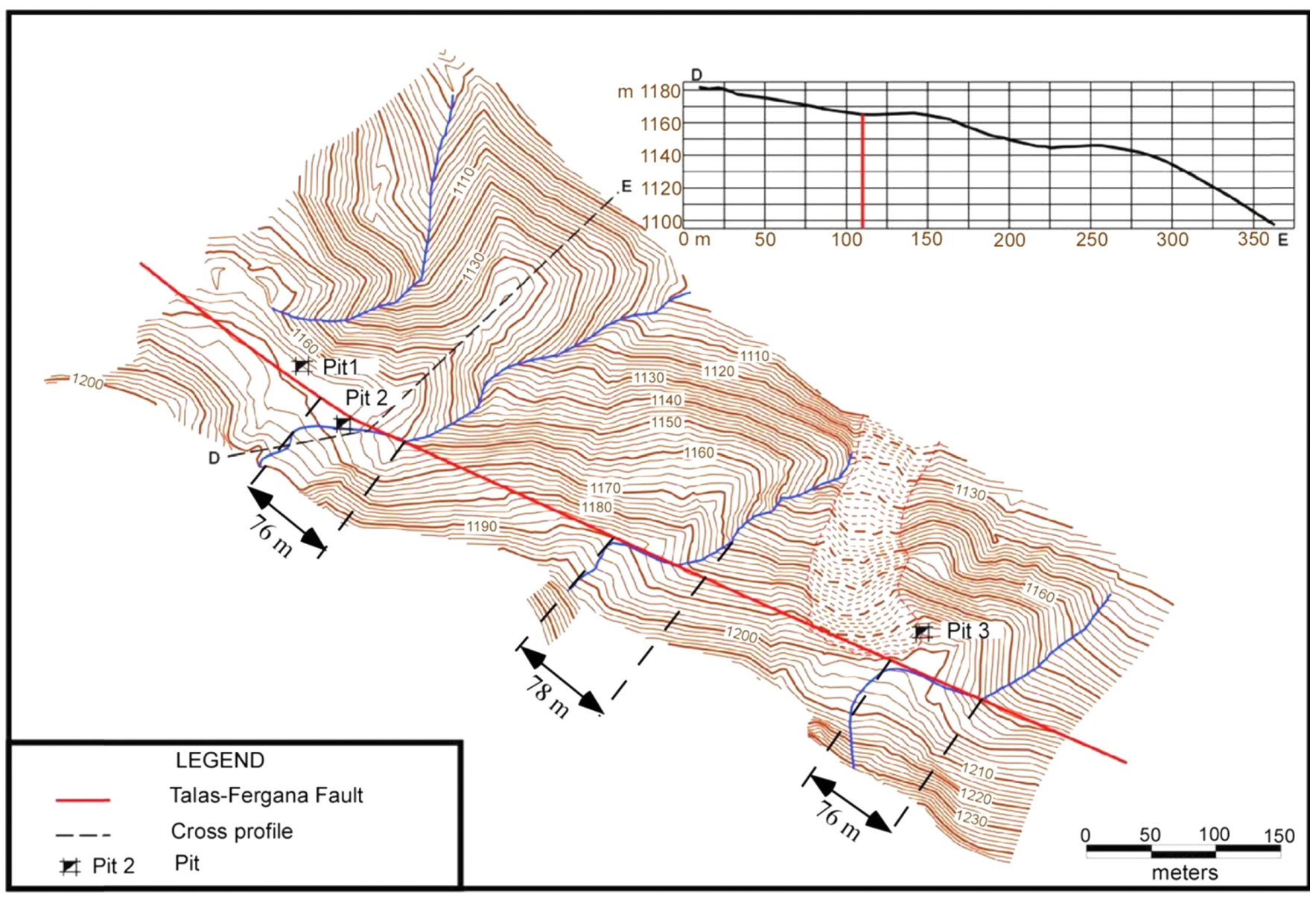

Figure 7. Detailed topographic map the Kok-Bel site, reconstructed by electronic tacheometer surveys. Values of right-lateral displacement of dry river beds are shown. Graph shows the topographic profile along the dashed line D-E. Pits 1, 2 and 3 are locations of paleoseismic trenching investigations. Location in Figure 6. Modified after Korjenkov et al. (2012).

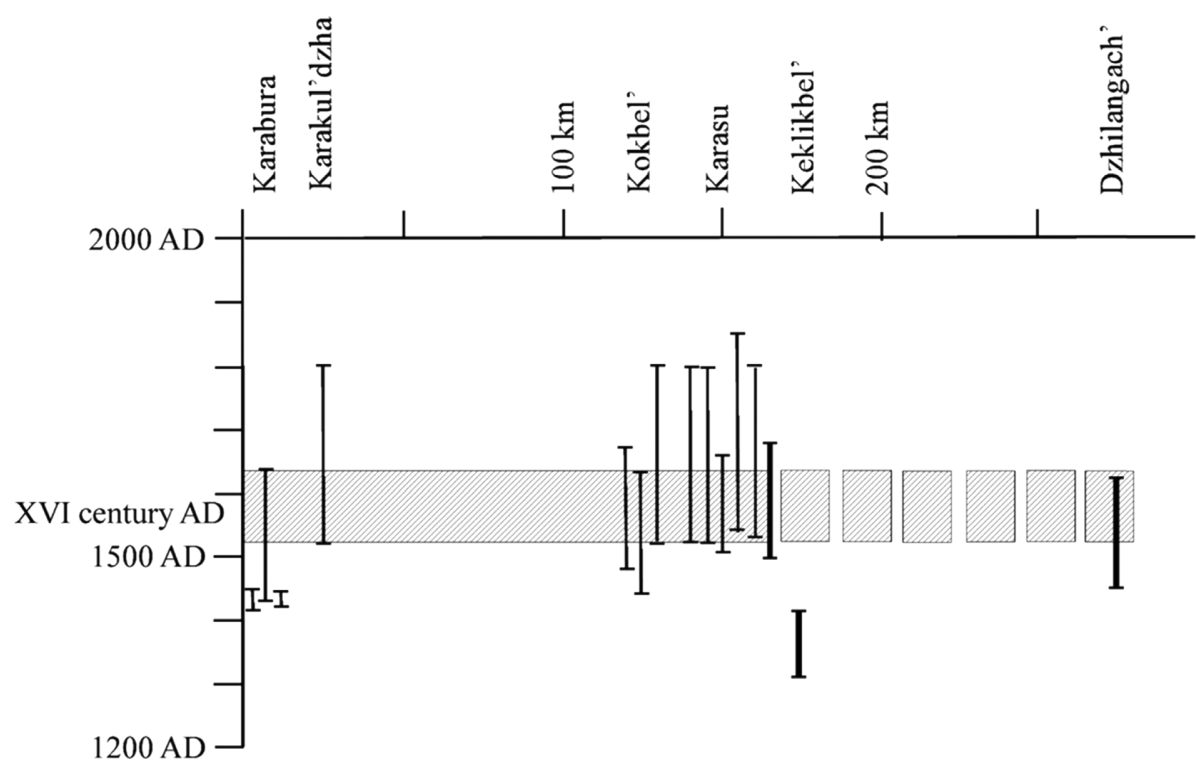

Figure 8. Calibrated radiocarbon ages of soil/paleosoil beds in the Talas-Fergana Fault zone resting above the strata affected by the last main earthquake (about 1500 A.D.). Thin and heavy lines are confidence intervals of recent soil and paleosoil ages, respectively.

able to estimate the rate of horizontal tectonic displacements along the fault, near the Toktogul HPS, at $13 \pm 1 \mathrm{~mm} / \mathrm{y}$. Here, the pronounced morphological expression of the Talas-Fergana Fault is consistent with our finding of the latest earthquake in the area, which hit about 500 ys ago (Korjenkov et al., 2010) (Fig. 8). Along the same fault, another two strong seismic events have been documented and dated at about 2400 and 5000 ys ago (Korjenkov et al., 2010).

Further paleoseismological studies along the fault allowed us to recognize a fault segment that was reactivated during two strong earthquakes that struck the area in the $14^{\text {th }}$ and $16^{\text {th }}$ centuries A.D. (Korzhenkov et al., 2013). The magnitude of the $16^{\text {th }}$ century event was at least 7.0 and the associated seismic intensity was IX. Near the southern coast of Toktogul lake, a number of offset alluvial fans of different ages indicates that repeated coseismic fault displacement occurred in Holocene times (Tibaldi et al., 2015). A trench which was opened across this fault segment provides evidence of the latest, major pre-historic earthquake that hit after $2617 \pm 430 \mathrm{yr}$ ago, with moment magnitude reaching 6.9. Based on the above, we believe that other, strong earthquakes might occur in the future along the studied 


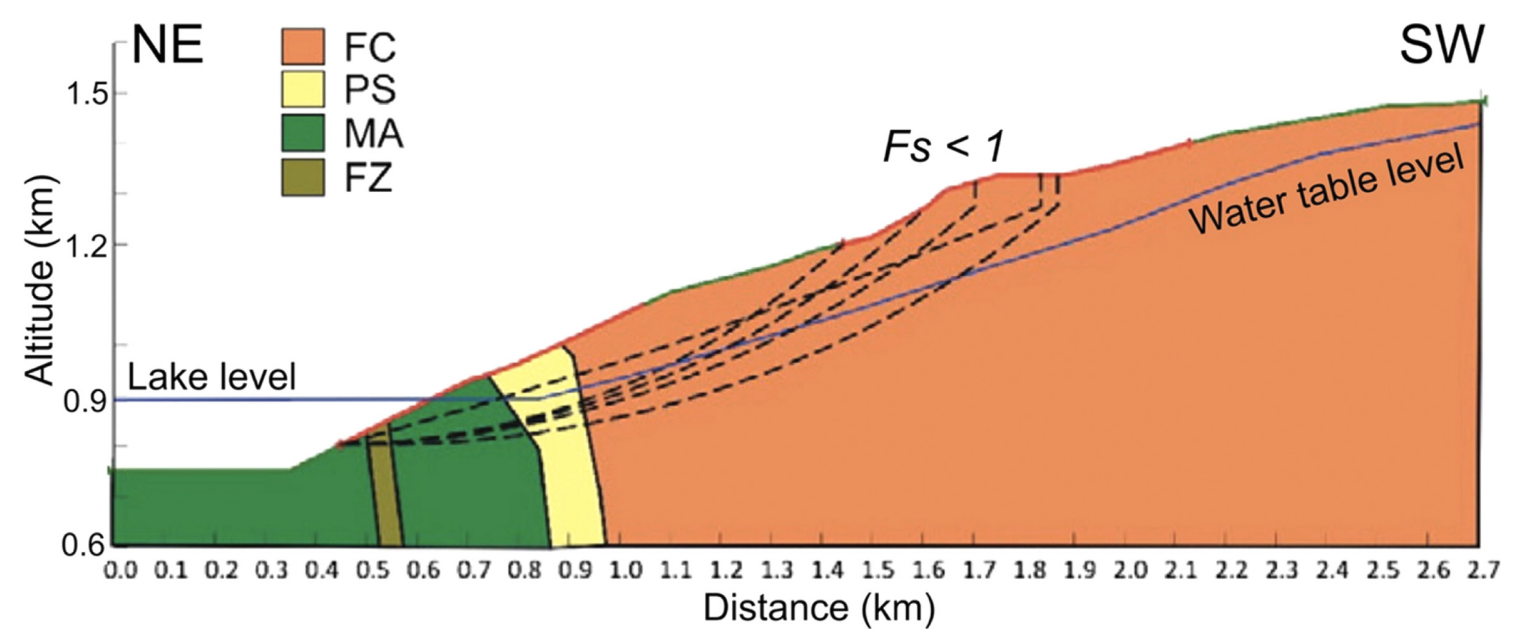

Figure 9. Pseudo-static numerical modelling of the slope facing the southern part of the Toktogul reservoir suggests that a rock mass with a volume of about $1 \mathrm{~km}^{3}$ is prone to slip toward the lake (Factor of safety, Fs $<1$ ) only in the event of a large earthquake in the area, corresponding to a seismic coefficient $k \geq 0.15$. FC: fossiliferous calcareous rocks, PS: phyllites and meta-sandstones, MA: marbles, FZ: TalasFergana Fault (fault gauge).

segment of the Talas-Fergana Fault.

Several huge rockslides have been recognized along the Talas-Fergana Fault near the Toktogul reservoir (Korzhenkov et al., 2014). Dating of these rockslides indicates they are much younger than the paleoearthquakes, suggesting that paleoearthquakes and significant landslides that are aligned along an active fault are not necessarily always coeval. However, the presence of a major fault might create a mechanical weakness zone possibly triggering new slope failures, as observed along major faults in the Alps (Tibaldi and Pasquaré, 2008).

We need to highlight that all rockslides present along the Karasu River valley segment of the Talas-Fergana Fault originated only from its southwestern slope. This phenomenon cannot be explained by invoking geological or geomorphologic differences between the two opposite valley sides, which are quite similar. Instead, it might be interpreted in terms of the seismogenic origin of these landslides that could be linked to the location and geometry of the seismogenic source, as was observed in other similar situations (e.g., Tibaldi et al., 1995).

Finally, we applied limit equilibrium methods focusing on the southwestern bank of the Toktogul reservoir, and performed a numerical analysis of the possible instability factors and the most likely slope failure mechanisms (Tibaldi et al., 2015). Static and pseudo-static analyses suggest a series of potential slip surfaces (Fig. 9); we used the deepest one to calculate a rock mass with a maximum volume of about $1 \mathrm{~km}^{3}$ that is prone to collapse only in the event of a large earthquake in the area, corresponding to a seismic coefficient $\mathrm{k} \geq 0.15$. As this landslide has the potential to generate a tsunami in the Toktogul reservoir, this possibility deserves further attention.

\section{Societal Implications}

The Toktogul HPS started operations in 1975, at a time when the region was under the USSR's rule and the present-day national borders did not exist. A very large area of the best agricultural lands in the Ketmen'-Tyube depression of Kyrgyzstan was covered by reservoir waters as a consequence of the dam construction. Tens of Kir- ghiz towns and villages were moved from the newly-flooded areas up to the hills. The Toktogul reservoir in present-day Kyrgyzstan was created in part for the irrigation of cotton fields in what is now Uzbekistan. Uzbekistan needs water for irrigation, especially during the summer, whereas Kyrgyzstan needs to maintain adequate reservoir levels at the end of the summer in order to generate hydro-electricity for winter heating. However, Uzbekistan does not have enough water reservoirs to store (for the summer period) the water released during the winter, as attested by floods that happened in the past. All these factors lead to tensions between the two neighbouring countries.

Additionally, Kyrgyzstan disagrees with the amount of money asked by Uzbekistan for natural gas. If an agreement is not reached, Kyrgyzstan may request a levy for its water flowing into Uzbekistan, which has been free until today.

These problems may escalate into a crisis, in case of droughts caused by global warming, or following a significant landslide(s) into the water reservoir (and a possible local tsunami) possibly triggered by a strong earthquake. These adverse events may have a major impact on operations at the Toktogul HPS, and may lead to variation in the water discharge that affects the Uzbekistan region downstream of the dam.

These linked feedback events could result in the activation of local religious and nationalistic elements. The Fergana Valley is a "powder keg" that needs only a spark to ignite the whole region, possibly leading to a regional war (Chellaney, 2013). That is why the assessment of earthquake and landslide hazard in the Toktogul region has a major scientific interest, as well as urgent, societal and geopolitical implications.

\section{The Caspian Oil and Gas Pipelines, Republic of Georgia}

\section{Geohazard Framework}

The cooperative, NATO-funded Georgian-Turkish-Italian-U.S. project, which lasted from 2007 to 2009 , was aimed at providing an essen- 


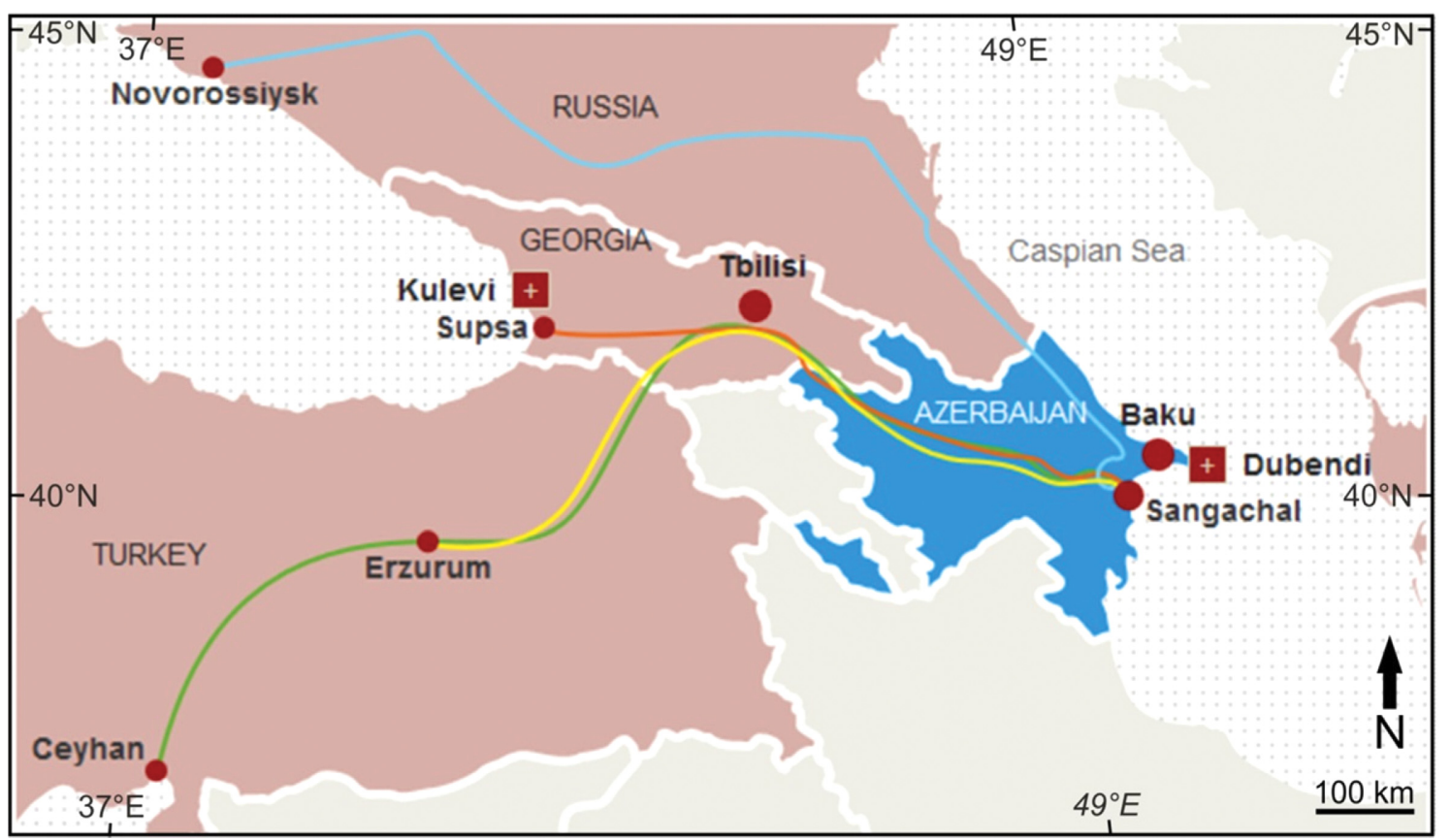

Figure 10. The Baku-Supsa (red) and the Baku-Tbilisi-Ceyhan (green) oil pipeline, as well as the South Caucasian natural gas pipeline (yellow), all traverse the Caspian region through Georgia, whereas the Baku-Novorossiysk (blue) runs through Azerbaijan and Russia.

tial understanding and assessment of the volcanic and seismic hazards threatening the Georgian section of the strategic Caspian oil and gas pipelines, particularly within the recent volcanics of the Javakheti plateau, and developing mitigation and protection measures against these natural hazards (Fig. 10). In the study area, the Baku-Tbilisi-Ceyhan (BTC) and the South Caucasian (SCP) pipelines run parallel (Pasquaré et al., 2011).

Along $70 \mathrm{~km}$ of this stretch the pipelines lie within the northern part of the Javakheti Plateau. This $2,500 \mathrm{~km}^{2}$ region is a high plateau (> $1500 \mathrm{~m}$ a.s.l.) with up to 100 major and minor volcanic centres (Lebedev et al., 2003; Kuloshvili and Maisuradze, 2004; Chernyshev et al., 2006; Pasquaré et al., 2011). The youngest volcanic area in the Javakheti plateau is the 40-km-long Abul-Samsari Volcanic Range (ASVR) (Fig. 11), dating to the Pleistocene and Holocene (Lebedev et al., 2003).

Recent K-Ar dating reported in Chernyshev et al. (2006) indicate that the ASVR volcanoes are active. The BTC and SCP pipelines cross the ASVR, with most of the volcanic risk posed by the Tavkvetili and Shavnabada volcanic edifices (Fig. 11). The area is also very active from the point of view of tectonic seismicity, as testified by the recent, 1986, M 5.6 Paravani earthquake, whose focal mechanism solution gives a NNE-SSW P-axis (Rebai et al., 1993). Moreover, there are several dip-slip and strike-slip faults with Holocene displacement. In particular, three fault sets that dissect the ASVR have a clear morphological expression and strike predominantly N-S, NWSE and NE-SW. The NW-SE fault set can be considered as the most important in the area, and had already been identified, through SPOT imagery, by Rebai et al. (1993), but who were not able to define its kinematics based solely on satellite image interpretation. The NATOsupported team conducted an extensive field tectonic analysis, aimed at finding evidence of NW-directed fault planes with striations, as well as defining the kinematics of this major fault set, recognized as a potential threat to the pipelines.

\section{Results}

The main results of this research effort are summarized below, whereas more data can be found in Pasquaré et al. (2011). Firstly, the analysis of the aerial photos, SPOT 5 satellite images (10-m resolution), DEMs with 20 m resolution and 1: 50,000 scale topographic maps, as well as the field surveys, enabled recognition that the Abul-Samsari Volcanic Range is composed of approximately 40 monogenetic volcanic centres, mainly lava cones with individual lava flows emanating from central vents, and subordinate scoria cones. Through geological field surveys, different types of eruptions and other volcanic events were identified and evaluated for expected future activity, with their likely distribution determined. Efforts were concentrated on the youngest edifices, Tavkvetili and Shavnabada, which are the closest to the pipelines track (Fig. 11). Tavkvetili is a 200 -m-high scoria cone that outpoured glassy lava flows towards the north and south. In fact the course of the pipeline is roughly coincident with the path of the northern lava flow from Tavkvetili. Shavnabada is a lava cone superimposed on an older edifice, and lavas flowed in east, south and west directions as far as the pediment of the Abul-Samsari range. Geomorphologic observations indicate the absence of periglacial activity on slopes, and the well-preserved summit craters suggest that volcanic activity probably postdates the last glacial retreat $(<10 \mathrm{Ka} \mathrm{BP})$. On the basis of our structural study (see below), we conclude that the $\sim$ NNE-SSW trending greatest principal stress $\sigma_{1}$ may bear serious implications for volcanic reactivation, that might take place as fissural eruptions and emplacement of localized vents along a NNE-SSW, tectonically-controlled vector. As the pipeline right of way is in close proximity to the north of Tavkvetili volcano, there may be increased volcanic risk that was not considered in the earlier pipeline design.

In terms of tectonic and seismic-related risks, the team's main result was the characterisation of the NW-SE fault system mentioned 


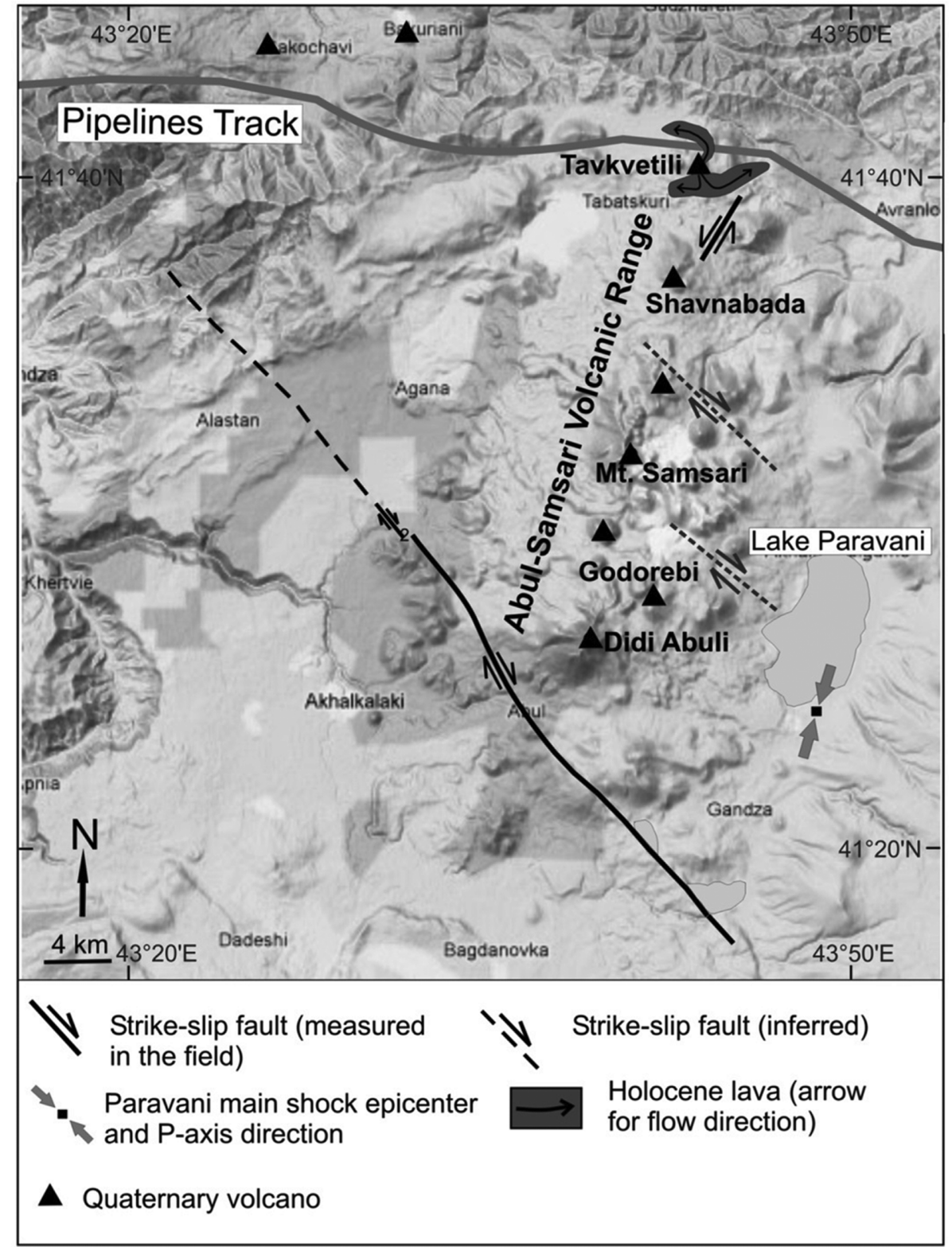

Figure 11. DEM of the ASVR, showing the main faults with indication of the related stress regime; P-axis from the Paravani earthquake. It is possible to observe a NNE-SSW-trending alignment of the Quaternary volcanoes, correspondent to the direction of compression. The post-glacial lava flow issued from Tavkvetili volcano is also highlighted. Modified after Pasquaré et al. (2011).

above, which was tracked in the field for $25 \mathrm{~km}$, as far as its NW tip (Fig. 11). A great number of fault planes was analysed, all bearing outstanding evidence of right-lateral strike-slip displacement. All the fault planes indicate, according to the freshness of their tectonic indicators, recent activity (e.g., Fig. 12). Fault plane striations were used to derive stress tensor orientations, with results univocally suggesting a NNE-SSW to N-S directed maximum horizontal compressive stress. Moreover, the analysis of aerial photos, DEMs and satellite images indicate a NW-ward prolongation of the fault, based on morphological evidence, for another $20 \mathrm{~km}$ to the NW (totalling $45 \mathrm{~km}$ in length) and coming very close $(12 \mathrm{~km}$ ) to the pipeline track (Fig. 11).

The NATO-supported team concluded that the documented strike- slip stress regime (and the related trend of the horizontal $\sigma_{1}$ ) can indeed be regarded as the one presently affecting the pipeline area. Moreover, in terms of seismic hazard and related risk to the pipeline, should the inferred $45-\mathrm{km}$-long fault rupture along its entire length, it would trigger a much greater shock than the abovementioned M 5.6 Paravani earthquake. Estimates based on Wells and Coppersmith (1994) for strike-slip faults, suggest a moment magnitude 7 as a worst-case scenario seismic event.

\section{Societal Implications: Threats to Vital Energy Links}

The Caspian region is rapidly becoming one of the major oil and gas producing areas in the world. After the breakup of the Soviet Union in 1991, the region opened to direct foreign investment and can provide petroleum to western markets. Much of the production comes from the Baku region of Azerbaijan, in particular from the giant Azeri-Chirag-Gunashli (ACG) oil field that lies about $100 \mathrm{~km}$ off the coast of Baku. The ACG field is being developed by a group of ten major petroleum companies from around the world. Georgia, situated in the central part of the Caucasian region, between the mountain ridges of Greater and Lesser Caucasus, is the natural transportation and pipeline corridor from the Caspian region to the West, and is also a crucial area geopolitically, as evidenced by the ongoing geopolitical pressure exerted by Russia. Therefore, it is paramount to take major efforts aimed at safeguarding the Georgian section of the pipeline. The possibility of future seismic, volcanic and related events across the right of way for these strategic pipelines has the potential to threaten these crucial energy links, affecting countries well beyond the borders of Azerbaijan, Georgia and Turkey. In addition to the risk of interrupted oil and gas supply, catastrophic leakages could affect the groundwater and springs that support one of the most important economic resources of Georgia: the Borjomi bottled water industry. This, in turn, could have destabilizing consequences for the economy of the whole country, as well as threatening important fauna and flora resources in the area of the BorjomiKharagauli National Park (Blatchford, 2005). The hazards for this park associated to a rupture of the pipeline include also the possibility of fires as a consequence of gas/oil leakages. In view of the above, the concluding part of this NATO research project was dedicated to a quantitative decision-making framework for potential new protective measures. 


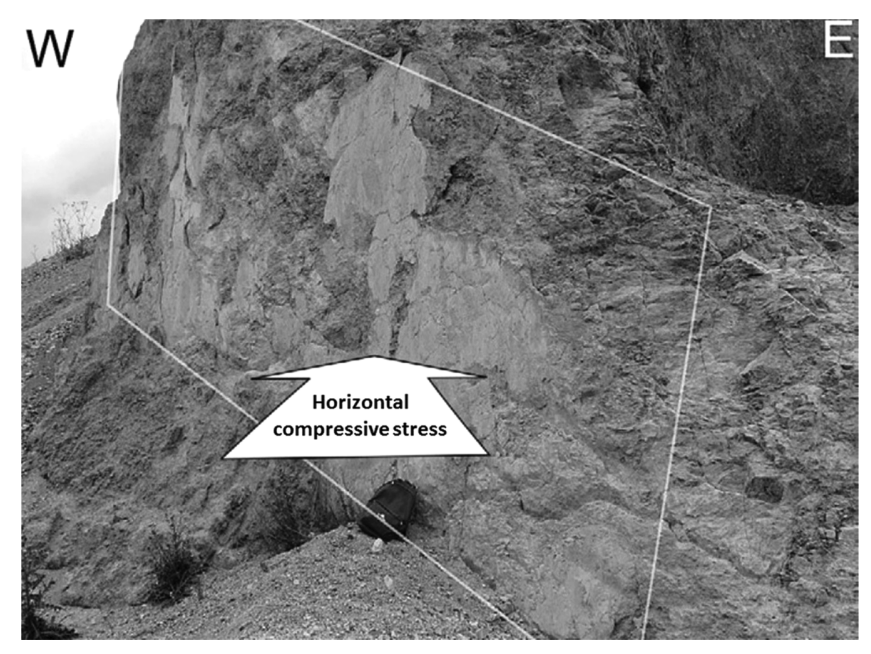

Figure 12. Picture of the $N W$-directed fault plane and indication of the $\sigma_{1}$ direction. Backpack for scale. A few tens of meters north of this outcrop, the fault dissects Holocene-age alluvial sediments. Modified after Pasquaré et al. (2011).

\section{Discussion and Conclusions}

\section{Main Scientific Outcomes}

At the Enguri hydroelectrical plant, we studied in detail an extensive active landslide directly entering the reservoir. Field data indicate continuous movements that affect a wide area involving also the important Jvary-Mestia road. Surveys conducted during the Soviet era also showed the presence of landslide deposits in the area that is now below the lake's level. Provisional numerical modelling in static conditions indicates that movement along deep rotational slip planes might occur especially during times of complete water saturation and during periods of major decrease in the reservoir level. All the above studies, although important, have not taken into account the dynamic conditions that may be induced by a high-magnitude earthquake in the area. Thus, the NATO-funded team decided to take three proactive actions: i) installing digital extensiometers and a GPS network of benchmarks for GPS measurements across the landslide, ii) initiating an extensive re-evaluation of the Peak Ground Acceleration at the landslide site based on the integration of new paleoseismic-structural investigations with historical and instrumental seismic data, and iii) increasing outreach efforts targeted to end-users, including the company that runs the dam and the relevant governmental stakeholders, in order to raise their awareness about the situation and make common decisions about future monitoring and mitigation measures.

At the Toktogul reservoir, the extensive work conducted along the Talas-Fergana Fault has made it possible to document that important earthquakes have occurred over the last thousands of years, involving fault sectors that are tens of kilometres long. Based on the relationship between surface fault rupture and earthquake magnitude (e.g., Mark, 1977; Bonilla et al., 1984; Wells and Coppersmith, 1994; Leonard, 2010), it can be suggested that events with $M>5$ may be expected in the area, up to at least M 7. The Toktogul dam is designed to resist seismic events of very high magnitude, but the problem here, once again, is the possibility of earthquake-triggered landslides collapsing into the reservoir. In this case, local conditions have made it difficult for NATO-scientists to create a tight collaboration with local authorities. Moreover, the remoteness of the area has prevented more extensive paleoseismological investigations, although a number of trenches across the fault have been excavated by hand (Korjenkov et al., 2012; Tibaldi et al., 2015; Rust et al., 2018).

The study along the Caspian pipelines has assessed and quantified seismic and volcanic geohazards that were not specifically considered in the original design of the BTC and SCP pipelines. Specifically, the NATO-funded research identified a major seismic hazard potentially affecting the pipeline track, in the form of a 45-km-long strike-slip fault that is capable of producing earthquakes with moment magnitude as great as 7 . However, although seismic-related damage to the pipelines would have serious economic consequences for Western Europe, the additional protection recommended by our study was not implemented.

\section{The Role of Earth Science}

By showcasing three NATO-funded projects, this paper has highlighted the role of Earth Science in taking proactive action aimed at reducing the possibility of societal and political crises linked to geological hazards. Needless to say, studies devoted to assessing natural hazards are not a novelty: Earth scientists have been working on these topics, in strict collaboration with protection agencies, for decades. Nevertheless, we wish to highlight that Earth Science can play an important role in preventing the occurrence of situations linked to natural disasters, the effects of which may exacerbate societal tensions, possibly leading to armed conflicts. This goal may be achieved by recognising the areas where a geological-related catastrophe can trigger an escalation of societal conflicts. Researchers belonging to different science domains have already been very active in areas subjected to economic, societal or political tensions, but the potential risks associated with geohazards may be overlooked if Earth scientists do not play an active role.

As an example, the Khoko landslide has been threatening the Enguri reservoir for tens of years, causing damage to the Jvari-Mestia road. Although this hazard has been known for a long time, remediation measures have never been implemented. In certain conditions, key activities such as land planning and risk monitoring are neglected by local and national authorities. However, thanks to the economic support provided by NATO, and to the active involvement of local and international Earth scientists, it has been possible to study the problem in detail, and to activate countermeasures aimed at enhancing preparedness for possible future adverse events. This was achieved especially by training local young researchers and setting up instruments capable of monitoring a possible escalation in slope movements, thus enabling Georgian public officials to take appropriate civil protection actions.

Another key aspect is represented by the necessity of establishing close relations with end-users at various levels, from the start of the research project. It is crucial to involve them as much as possible in the various phases of work, as well as to reach joint final decisions on follow-up activities. As an example, due to the lack of formal contacts with the companies that run the Caspian pipelines, the recommendations made as a result of the NATO project were not put in 
practice.

Despite widespread progress in studying geohazards, many regions of the world are exposed to still unrecognized threats. In these regions, poverty is still a major issue, which can be worsened by the occurrence of extreme natural events. Our work emphasizes how important it is to build up research teams spanning the broadest spectrum of the Earth Sciences, and to support them in studying regions subjected to a combination of geohazards and geopolitically critical conditions. In doing so, geologists will have a chance to show that, together with scientists from other key disciplines, they can actively contribute to a safer and more peaceful global society.

\section{Acknowledgements}

We are grateful to Massimiliano Pittore and Elena Nikolaeva for their very useful suggestions on an earlier version of the manuscript. The work at Enguri has been carried out with funding from NATOSFP project G4934, under the coordination of A. Tibaldi and N. Tsereteli. The work at Toktogul was developed with funding from NATOSFP project 983142, under the coordination of D. Rust and A.M. Korzhenkov. The studies on the pipeline were conducted with funding from NATO project CLG 982957, under the leadership of F. Pasquaré Mariotto. Several colleagues from different countries, who collaborated in these research efforts, are acknowledged. Among these are co-Directors G. Babayev, J. Gierke and A. Sultanbekova, and collaborators F.L. Bonali and C. Corazzato. P. Oppizzi is acknowledged for the crucial role he played in installing the extensiometers at Enguri (Georgia) and for preparing Figure $5 \mathrm{~b}$.

\section{References}

Babayev G., Ismail-Zadeh, A., and Le Mouel J.-L., 2010, Scenario-based earthquake hazard and risk assessment for Baku (Azerbaijan). Natural Hazards and Earth System Sciences, v. 10, pp. 2697-2712.

Blatchford, D., 2005, Environmental and social aspects of the BakuTbilisi-Ceyhan pipeline. In: Frederick Starr, S., and Cornell, S.E. (Eds.), The Baku-Tbilisi-Ceyhan Pipeline: Oil Window on the West. Central Asia-Caucasus Institute and Silk Road Studies Program, pp. 119-150.

Bonilla, M.G., Mark, R.K., and Lienkaemper, J.J., 1984, Statistical relations among earthquake magnitude, surface rupture length, and surface fault displacement. Bulletin of the Seismological Society of America, v. 74, pp. 2379-2411.

Burtman, V.S., Skobelev, S.F., and Sulerzhitsky, L.D., 1987, The TalasFergana Fault: recent offsets in the Chatkal district of the Tien Shan. Doklady Akademii Nauk SSSR, v. 296, pp. 1173-1176.

Burtman, V.S., Skobelev, S.F., and Molnar, P., 1996, Late Cenozoic slip on the Talas-Fergana fault, the Tien Shan, Central Asia, Geological Society of American Bulletin, v. 108, pp. 1004-1021.

Chelidze, T., Javakhishvili, Z., Varazanashvili, O., Elashvili, M., Kolesnikov, Yu., Godoladze, T., Butikashvili, N., and Ghlonti, E., 2002, Seismic hazard assessment of Georgia (probabilistic approach). http://drm.cenn. org/Hazard_assessment_files/eng/Seismic_hazard_assessment_of_Georgia.pdf

Chellaney, B., 2013, Water, peace, and war: confronting the global water crisis. Rowman \& Littlefield, Lanham, 399 p.

Chernyshev, I.V., Lebedev, V.A., and Arakelyants, M.M., 2006, K-Ar dating of Quaternary volcanics: methodology and interpretation of results.
Petrology, v. 14, pp. 62-80.

Griffin, M.J., Bragagnolo, L.J., and Yanev, P.I., 1991, The December 7, 1988, Armenia earthquake: effects on selected power, industrial, and commercial facilities. Report EPRI-NP-7359-M, Electric Power Research Institute, Alto, US, 103 p. http://drm.cenn.org/Hazard_assessment_files/ eng/Seismic_hazard_assessment_of_Georgia.pdf

Korjenkov, A.M., Bobrovskii, A.V., and Mamyrov, E.M., 2010, Evidence for strong paleoearthquakes along the Talas-Fergana Fault near the Kok-Bel Pass, Kyrgyzstan. Geotectonics, v. 44, pp. 262-270.

Korjenkov, A., Rust, D., Tibaldi, A., and Abdieva, S., 2012, Parameters of the strong paleoearthquakes along the Talas-Fergana Fault, the Kyrgyz Tien-Shan. In: D'amico, S. (Ed.), Earthquake Research and Analysis Seismology, Seismotectonics and Earthquake Geology. InTech Publishers, Rijeka, Croatia, pp. 33-84.

Korzhenkov, A.M., Abdieva, S.V., Burtman, V.S., Orlova, L.A., Rust, D., and Tibaldi, A., 2013, Indications of late medieval earthquakes in the Talas-Fergana Fault Zone, Tien Shan. Geotectonics, v. 47, pp. 444-453.

Korzhenkov, A.M., Abdieva, S.V., Belousov, T.P., Rust, D., and Tibaldi, A., 2014, An age of rockslides and palaeoearthquakes in the Karasu River valley (Talas-Fergana Fault, Kyrgyzstan). Seismic Instruments, v. 50, pp. $97-108$.

Kuloshvili, S.I., and Maisuradze, G.M., 2004, Recent volcanism and neotectonics of the South Georgian, Armenian and East Anatolian (Kars) volcanic highlands. Proceedings of Georgian Academy of Sciences, new service, v. 119, pp. 139-149. (in Russian)

Lebedev, V.A., Chernishev, I.V., Dudauri, O.Z., Arakelyants, M.M., Bairova, E.D., Gol'tsman, Yu.V., and Vashakidze, G.T., 2003, The Samsari Volcanic Centre as an example of recent volcanism in the Lesser Caucasus: K-Ar geochronological and Sr-Nd isotopic data. Doklady Earth Sciences, v. 393A, pp.1323-1328.

Leonard, M., 2010, Earthquake fault scaling: self-consistent relating of rupture length, width, average displacement, and moment release. Bulletin of the Seismological Society of America, v. 100, pp. 1971-1988.

Mark, R.K., 1977, Application of linear statistical models of earthquake magnitude versus fault length in estimating maximum expectable earthquakes. Geology, v. 5, pp. 464-466.

Nikolaeva, E., and Walter, T.R., 2016, InSAR observations of the 2009 Racha earthquake, Georgia. Natural Hazards and Earth System Sciences, v. 16, pp. 2137-2144.

Pasquaré, F., Tormey, D., Vezzoli, L., Okrostsvaridze, A., and Tutberidze, B., 2011, Mitigating the consequences of extreme events on strategic facilities: evaluation of volcanic and seismic risk affecting the Caspian oil and gas pipelines in the Republic of Georgia. Journal of Environmental Management, v. 92, pp. 1774-1782.

Philip, H., Cisternas, A., Gvishiani, A., and Gorshkov, A., 1989, The Caucasus: an actual example of the initial stages of continental collision. Tectonophysics, v. 161, pp. 1-21.

Rebai, S., Philip, H., Dorbath, L., Borissoff, B., Haessler, H., and Cisternas, A., 1993, Active tectonics in the Lesser Caucasus: coexistence of compressive and extensional structures. Tectonics, v. 12, pp. 1089-1114.

Reilinger, R.E., McClusky, S.C., Vernant, P., Lawrence, S., Ergintav, S., Cakmak, R., Ozener, H., Kadirov, F., Guliev, I., Stepanian, R., Nadariya, M., Hahubia, G., Mahmoud, S., Sakr, K., Arrajehi, A., Paradissis, D., Al-Aydrus, A., Prilepin, M., Guseva, T., Evren, E., Dmirotsa, A., Filikov, S.V., Gomez, F., Al-Ghazzi, R., and Karam, G., 2006, GPS constraints on continental deformation in the Africa-Arabia-Eurasia continental collision zone and implications for the dynamics of plate interactions. Journal of Geophysical Research, v. 111. https://doi.org/10.1029/ 2005JB004051

Rust, D., Korjenkov, A., and Tibaldi, A., 2018, Geologic slip-rate determinations on the Talas-Fergana fault: mismatch with low geodetic slip rate. Geophysical Research Letters. https://doi.org/10.1002/2017GL076990

Tibaldi, A., and Pasquaré, F., 2008, Quaternary deformations along the 'Engadine-Gruf tectonic system', Swiss-Italian border. Journal of Quaternary Science, v. 23, pp. 475-487. 
Tibaldi, A., and Pasquarè Mariotto, F., 2017, The struggle between Abkhazia and Georgia, as observed from NATO-supported scientists. Associazione di Studio, Ricerca ed Internazionalizzazione in Eurasia ed Africa (ASRIE). www.asrie.org/2017/06/the-struggle-between-abkhazia-and-georgia-as-observed-from-nato-supported-scientists/

Tibaldi, A., Ferrari, L., and Pasquaré, G., 1995, Landslide triggered by earthquakes and their relationships with faults and mountain slope geometry: an example from Ecuador. Geomorphology, v. 11, pp. 215226.

Tibaldi, A., Corazzato, C., Rust, D., Bonali, F.L., Pasquaré Mariotto, F., Korzhenkov, A.M., Oppizzi, P., and Bonzanigo, L., 2015, Tectonic and gravity-induced deformation along the active Talas-Fergana Fault, Tien Shan, Kyrgyzstan. Tectonophysics, v. 657, pp. 38-62.

Tibaldi, A., Alania, V., Bonali, F.L., Enukidze, O., Tsereteli, N., Kvavadze, N., and Varazanashvili, O., 2017, Active inversion tectonics, simple shear folding and back-thrusting at Rioni Basin, Georgia. Journal of Structural Geology, v. 96, pp. 35-53.

Trifonov, V.G., Korzhenkov, A.M., and Khaled, O.M., 2015, Recent geodynamics of major strike-slip zones. Geodesy and Geodynamics, v. 10, pp. 1-23.

Trifonov, V.G., Makarov, V.I., and Skobelev, S.F., 1992, The Talas-Fergana active right-lateral fault. Annales Tectonicae, v. VI, pp. 224-237.

Tsereteli, N., Arabidze, V., Varazanashvili, O., Gugeshashvili, T., Mukhadze, T., and Gvencadze, A., 2014, Vulnerability analysis and GIS based seismic risk assessment Georgia case. In: Teodorescu, H.-N., Kirschenbaum, A., Cojocaru, S., and Bruderlein, C. (Eds.), Improving Disaster Resilience and Mitigation - IT Means and Tools. NATO Science for Peace and Security Series C: Environmental Security, Springer, Dordrecht, pp. 307-321.

Tsereteli, N., Tibaldi, A., Alania, V., Gventsadse, A., Enukidze, O., Varazanashvili, O., and Müller, B.I.R., 2016, Active tectonics of centralwestern Caucasus, Georgia. Tectonophysics, v. 691, pp. 328-344.

Van Westen, C.J., Straatsma, M.W., Turdukulov, U.D., Feringa, W.F., Sijmons, K., Bakhtadze, K., Janelidze, T., and Kheladze, N., 2012, Atlas of Natural Hazards and Risk in Georgia. CENN/ITC Caucasus Environmental NGO network \& Faculty of Geo-Information Science and Earth Observation, Tbilisi, $110 \mathrm{p}$.

Varazanashvili, O., Tsereteli, N., and Tsereteli, E., 2011, Historical Earthquakes in Georgia (up to 1900): Source Analysis and Catalogue Compilation. Monograph, M. Javakhishvili Tbilisi State University, Georgia, $81 \mathrm{p}$.

Varazanashvili, O., Tsereteli, N., Bonali, F.L., Arabidze, V., Russo, E., Pasquarè Mariotto, F., Gogoladze, Z., Tibaldi, A., Kvavadze, N., and Oppizzi, P., 2018, GeoInt: the first macroseismic intensity database for the Republic of Georgia. Journal of Seismology, v. 22, pp. 625-667.

Vincent, S.J., Carter, A., Lavrishchev, V.A., Price, S.P., Barabadze, T.G., and Hovius, N., 2011, The exhumation of the western Greater Caucasus: a thermochronometric study. Geological Magazine, v. 148, pp. 1-21.

Wells, D.L., and Coppersmith, K.J., 1994, New empirical relationships among magnitude, rupture length, rupture width, rupture area, and surface displacement. Bulletin of the Seismological Society of America, v. 84, pp. 974-1002.

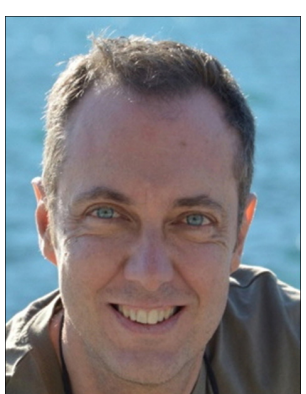

Alessandro Tibaldi is Ph.D. in earth sciences, full professor of structural geology, rectordelegate of International Affairs with the USA at the University of the Studies of Milan Bicocca (Italy), coordinator for Internationalisation of the Department of Earth and Environmental Sciences, ad-hoc Graduate Faculty at Michigan Technological University (USA). Chairperson Committee of National Representatives of International Lithosphere Program, author of 3 scientific books and more than 140 academic articles, member of the Editorial Board of Frontier in Earth Sciences. His main research interests are on recent/active tectonics, volcanotectonics and geohazards.

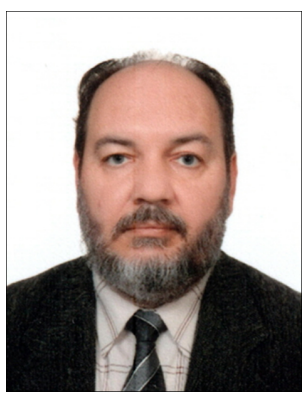

Andrey M. Korzhenkov is head of Laboratory of Seismic Processes Modeling, Institute of Communications and Information Technologies, Kyrgyz-Russian Slavic University, (co)author of more than 300 scientific publications. He has got his Doctor degree (Dr. Habil.) in Geological and Mineralogical Sciences, from Institute of Geology, NAS KR in 2007. He has been awarded by Alexander Von Humboldt Foundation research fellowship from Potsdam University, Germany during 2000-2002. His areas of expertise include archeoseismology, active tectonics, tectonic geomorphology, paleoseismology, and integrated investigation of earthquake hazards in the Tien Shan, Middle East and Caucasus mountains.

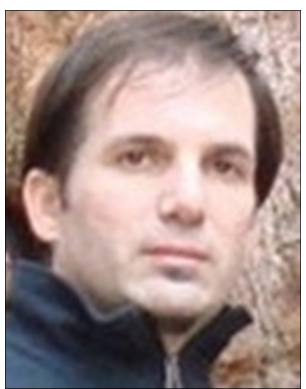

Federico Pasquaré Mariotto is an associate professor at the Department of Theoretical and Applied Sciences of the University of Insubria, Varese (Italy), where he teaches Environmental Hazard Communication, Science Communication and Introduction to Volcanology. Author of more than 60 academic articles, most of which published in International, peer review-based Journals, President of the Association "GeoSocial Science \& Media”, dedicated to Geoscience Communication. 